Article history:

Received: 15 January 2020;

Revised: 31 January 2020;

Accepted: 15 February 2020;

Available online: 24 February 2020

\title{
Analyzing the Influence of Quality, Price, and After-Sales Service of 5 Sedan Low Category to Consumer Satisfaction
}

\author{
Dwi Irawati ${ }^{1}$, Yuni Siti Nuraeni ${ }^{2}$ \\ ${ }^{12}$ Universitas Bina Sarana Informatika \\ dwi.dii@bsi.ac.id
}

\begin{abstract}
The demand for private transportation that comfort, cheap, and good quality has been increasing lately. It caused many companies to launch any car that can answer the request. Refer to Indonesia, people that like most to visit each other and traveling created an increasing demand for this type of car. The Indonesian automotive market launch type of car that has a sedan category but has a small shape, it called the city car. City car has answered the demand for many consumers especially for a little family with two or more children who want to have a small vehicle completed with comfort, cheap and excellent quality features so that my research is to proof is there any relation between quality, price and after-sales service according to consumer satisfaction to 5 best seller refer to web otomotif.kompas.com, they are Toyota Agya, Daihatsu Ayla, Honda Brio Satya, Suzuki Wagon $\mathrm{R} 15$ dan Datsun GO+. The result of this research is proving that quality, price, and after-sales service has a connection to consumer satisfaction.
\end{abstract}

Keywords: product quality, price, aftersales service, consumer satisfaction

\section{Introduction}

In the world of business, competition cannot be avoided by business people in a growing fastgrowing business market; one of the fast-growing company is an automotive business in a sector of transportation. The car is a product that is included in the type of Specialty Goods, where to buy products that stand in the Special Goods Goods consumers or buyers are willing to do unique business, for example, brand consideration, quality, and so on.

Nowadays, there are so many brands of the car with various models, designs, with quality choices and competitive prices. For companies engaged in the automotive sector, this condition is an opportunity to gain market share in the transportation sector. There are many automotive companies in Indonesia, including Honda, Toyota, Daihatsu, Suzuki, Nissan, and others.

Based on data from Gaikindo (Association of Indonesian Automotive Industries) quoted from the gaikindo website, it explains that the Indonesian automotive industry experienced ups and downs from 2003-2014 (Kotler, 2003). Still, from 2010 - 2014, there was a continuous increase in market demand.

Below is the best-selling city car sales data for 2015, quoted from the website Kompas.com.

${ }^{1}$ Korespondensi: Dwi Irawati, Universitas Bina Sarana Informatika, Jl. Salemba Tengah No.45. Senen, Kota Jakarta Pusat. dwi.dii@bsi.ac.id

${ }^{2}$ Korespondensi: Yuni Siti Nuraeni, Universitas Bina Sarana Informatika, Jl. Salemba Tengah No.45. Senen, Kota Jakarta Pusat. yuni.yns@bsi.ac.id 
Table 1. The Best- Selling City Car sales 2015

\begin{tabular}{|c|l|r|}
\hline No & \multicolumn{1}{|c|}{ Brands } & Unit \\
\hline 1 & Toyota Agya & 56.361 \\
\hline 2 & Daihatsu Ayla & 35.856 \\
\hline 3 & Honda Brio Satya & 21.959 \\
\hline 4 & Suzuki Wagon R 15 & 15.411 \\
\hline 5 & Datsun GO+ & 13.536 \\
\hline 6 & Honda Brio & 9.853 \\
\hline 7 & Toyota Etios Valco & 8.560 \\
\hline 8 & Mitsubishi Mirage & 4.743 \\
\hline 9 & Nissan March & 3.988 \\
\hline 10 & Kia Picanto & 3.376 \\
\hline
\end{tabular}

Consumers are faced with a variety of prices, product excellence, and service services offered by each manufacturer. Consumer satisfaction is a priority for producers in marketing their products.

Therefore the author wants to analyze whether there is a relationship between price, product quality, and after-sales service of city car cars to consumer satisfaction. Because consumer satisfaction is a determinant of loyalty to the use of the product in the long run, and that means being a benefit for producers. Based on the above problem limitation, some research questions can be formulated as follows:

1. Is there an effect of City Car product's prices on customer satisfaction?

2. Is there an influence on the quality of City Car products on customer satisfaction?

3 . Is there any influence after-sales service City Car product on customer satisfaction?

4. Is there an influence between the price, the quality, and the after-sales service of City Car products together on customer satisfaction?.

\section{Literature Review}

\section{Consumer satisfaction}

According to (nazir, 2009) consumers will buy from companies that they believe offer the value that consumers think. The amount that is believed to by the consumer is the difference between the evaluation of the prospective customer of all benefits and all the costs of a particular offer with other alternatives that are considered.

Satisfaction is determined by the mismatch of expectations, which is a comparison between perceived performance and expectations (Oliver, 1993). Satisfaction or dissatisfaction is the response to the evaluation of perceived discrepancies between previous expectations and product performance after usage (Wilton, 1988).

(engel, Blackwell, miniard, 1990) define satisfaction as an after-purchase evaluation of selected alternatives that produce the same or exceeding expectations. (Kotler, 2003) argues, pleasure is the level of one's feelings after comparing the perceived performance versus expectations. Satisfaction is an affective statement about an emotional reaction to the experience of a product/service that is influenced by customer satisfaction with the product and with the information used to select the product (Spreng, MacKenzie, \& Olshavsky, 1996).

\section{Product quality}

According to (Kotler and Armstrong, 2004, p. 283), the meaning of product quality is the ability of a product to demonstrate its function; it includes the overall durability, reliability, accuracy, ease of operation and product repairs as well as other product attributes. According to (Tjiptono, 2000, p. 54), product quality has a very close relationship with consumer attitudes, 
where product quality provides an impetus for consumers to establish a strong relationship bond with the company.

While the dimensions of the product attribute used by (Mittal, Kumar, \& Tsiros , 1999) are applied to the manufacturing industry as follows:

a. Convenience

In the eyes of consumers, the more comfortable a product will improve the high quality of the product so that it will provide satisfaction to consumers.

b. Completeness

With the completeness of the vehicle, which is getting higher/more complete, it will increase the sense of comfort and customer satisfaction.

c. Reliability

In the increasingly fierce competition in this globalization era, a truly reliable product is needed, so that it will help in consumer mobility.

d. Transmission Gear

Smooth transmission gearshift indicates high product quality, thereby increasing acceleration.

e. Brake

The function of quality braking will indicate high product quality, and this is the needs and desires of consumers that must be met for a sense of security.

\section{Price}

Price, according to (Kotler and Armstrong, 2001), is the amount of money exchanged for a product or service. Furthermore, price is the amount of value that consumers exchange for the amount of benefit by owning or using an item or service.

According to (Swasta, 2001), price is the amount of money (plus a few items if possible) needed to get a combination of goods and their services.

According to (Stanton, 1998, p. 308), there are four indicators that characterize prices, namely:

a. Affordability of costs, i.e., aspects of pricing done by producers/sellers that are in accordance with consumers' purchasing abilities.

b. Price competitiveness, i.e., the price offer given by the producer/seller is different and competes with that provided by other producers, on the same type of product.

c. Price conformity with product quality, i.e., aspects of pricing done by producers/sellers in accordance with the product quality that can be obtained by consumers.

d. Price conformity with product benefits, i.e., aspects of pricing done by producers/sellers in accordance with the benefits consumers can obtain from the product purchased.

\section{After-sales service}

(Kotler P. , 2002, p. 508) said that after-sales service is a service provided by a company to a consumer after a sales transaction.

According to (Kotler and Keller, 2005, p. 133), after-sales service is to provide the best support; companies provide after-sales service, most companies move through several stages. According to (Hendra Teguh, Ronny A. Rusli , 2000, p. 100), defines that after-sales service as all forms of service provided by the company to consumers after the sale, such as maintenance and repair services and customer service.

Meanwhile, according to (Hindle and Thomas in Fandy Tjiptono, 2008), After-sales service is a service provided by producers to consumers after consumers buy products from the company.

After-sales service has several elements, as stated by (Kotler P. , 2002) that the components in after-sales service are as follows: 
a. Guarantee is one of the most critical factors in carrying out after-sales service, as stated by (Kotler P. , 2002, p. 508) that the warranty is intended to convince consumers that the product is in good condition or free from damage, as a result of inaccuracy in handling or improper use of material that is valid for a specified period.

b. Provision of Accessories, in the implementation of after-sales service, the supply of spare parts is crucial because, without any product parts that have been damaged, the components cannot function properly, even the product cannot be used anymore. So the provision of accessories is one factor that plays a vital role in satisfying consumers, which in turn will maintain customer loyalty that is already owned.

c. Service and maintenance and repairs are needed if a product has a long consumption period and requires regular maintenance so that it can always function properly, and also to make repairs for damage caused to the product during its use.

d. Facilities and equipment of a product are a means for conducting after-sales service. Sophisticated equipment and equipment will be able to determine the smooth function of officers in carrying out maintenance and repair of products purchased by consumers.

\section{Hypothesis}

Based on the theoretical description, it is suspected that there is an influence of product quality, price, and after-sales service on the consumer satisfaction of the city car. Thus, the research hypothesis is as follows:

H1: Product quality affects customer satisfaction.

H2: Price affects customer satisfaction.

H3: After-sales service affects customer satisfaction.

H4: Product quality, price, and after-sales services simultaneously affect customer satisfaction.

\section{Method}

The design of this study uses quantitative methods using SPSS (Statistical Product and Service Solutions). Questionnaires will be given to city car consumers in the lower class sedan category domiciled in DKI Jakarta. The car brand restrictions are imposed on five-city car brands, namely: Toyota, Honda, Daihatsu, Suzuki, and Datsun. Consumers of users of the five-car brands who are research respondents, the data based on the questionnaire will be tabulated and then tested the instrument. The next process will be carried out by making a regression test.

In this study, the authors use quantitative research methods, which consist of the dependent variable (dependent) and independent variables (independent) in the form of the variable $\mathrm{Y}$ as the dependent variable in this case the $\mathrm{Y}$ variable is Consumer Satisfaction. Whereas the variable X1 is Quality, X2 is Price, and X3 is After-Sales Service for low-class city car sedans as free variables. This method is used to determine the effect of quality, price, and after-sales service for low-class city car sedans on customer satisfaction.

According to (Sugiyono, 2010), the population is a generalization area consisting of objects or subjects that have certain qualities and characteristics that are determined to be studied and studied and then conclusions drawn. In this study, the population used is the owner of a low-class city car sedan in the Greater Jakarta area.

This study was not conducted on all populations but in a portion of the target population (sample). The sampling technique using nonprobability sampling is a sampling technique that does not give equal opportunity or opportunity for each element or member of the population to be selected as a sample (Sugiyono, 2014, p. 154). The sampling technique chosen is incidental sampling, which is a sampling technique based on coincidence, i.e., anyone who accidentally or 
incidentally meets with the researcher can be used as a sample if it is deemed that the person met by chance is suitable as a source of data deliberately according to the required sample requirements.

In this study, the authors decided to research 200 respondents; it was by the criteria, according to Frankel and Wallen, for descriptive studies of at least 100 samples and also the limitations of time, cost, and energy of the author in conducting this study. The questionnaire was given directly through data collection by submitting a list of questions or statements to the owner of the city car in the DKI Jakarta area.

The measurement scale used is a Likert scale, wherein filling out the questionnaire, respondents determine their level of agreement with a statement by choosing one of the available choices. Some tests conducted on the data obtained include:

1. A validity test is used to measure the validity or validity of a questionnaire. A questionnaire is said to be valid if the questions on the survey can reveal something that will be measured by the study (Ghozali, 2005).

2. The reliability test is used to test the consistency of the respondents' answers. The formula used to test the reliability of an instrument can be seen from Cronbach's Alpha, where the device is declared reliable if the Cronbach's Alpha value is at least 0.6. (Muhidin, 2007, p. 37).

3. Test requirements analysis aims to determine the condition of the data used in research. This is done to obtain the right analysis model. To find out the variables that are feasible to be used in the regression model, a classic assumption test is used,

4. Correlation Test is a statistical technique used to test whether there is a reciprocal relationship between two or more variables. The size of the relationship between two variables is expressed in numbers called correlation coefficients.

5. Multiple Regression Analysis, this technique is used if the researcher intends to predict how the condition (ups and downs) of the dependent variable, if two or more independent variables as a predictor factor is manipulated (raised the value down). So multiple regression analysis will be conducted if the number of independent variables is at least two (Riduwan, 2009). The formula is:

Where:

$$
\mathrm{Y}=\mathrm{a}+b_{1} X_{1}+b_{2} X_{2}+b_{3} X_{3}+\mathrm{e}
$$

$\mathrm{Y}=$ Purchase Decision

$\mathrm{a}=$ Constant number (value of $\mathrm{y}$ in terms of $\mathrm{b}_{1} \mathrm{X}_{1}+\mathrm{b} 2 \mathrm{x}_{2}+\ldots+\mathrm{e}=0$ )

$\mathrm{b}=$ Regression Coefficient

$\mathrm{X}_{1}=$ Product Quality variable score

$\mathrm{X}_{2}=$ Price variable score

$\mathrm{X}_{3}=$ After Sales Service Variable Score

$\mathrm{e}=$ Effect of other variables

6. This t-test is carried out to determine whether there is an effect of Product Quality on Consumer Satisfaction, prices on Consumer Satisfaction, and after-sales service on customer satisfaction.

7. Simultaneous hypothesis testing uses the F test, where the value of $F$ count is compared with the amount of $\mathrm{F}$ table at a certain level of confidence.

8. Correlation coefficient test (R) and determination (R2) to measure how far the model's ability to apply the related variables. The next step is to find the regression coefficients for each independent variable, which is to find out which independent variable contributes the most to the dependent variable 


\section{Results}

1. Validity Test

Validity Test is used to measure the validity of a questionnaire. A questionnaire is said to be valid if the questions on the survey can reveal something that will be measured by the study.

The validity test results for eight items of Consumer Satisfaction variable statement obtained six statements that have $r$ count $>r$ table and declared valid. However, two comments are invalid because they have $\mathrm{r}$ count $<\mathrm{r}$ table, namely numbers 3 and 5 .

The results of the comparison between $r$ arithmetic and $r$ tables for 12 items of the quality variable statement obtained eight statements that have $r$ arithmetic $>r$ table and declared valid. But there are four invalid statements because they have $r$ count $<r$ table, namely numbers 13 , 14,15 , and 20.

Validity Test Results 10 items of variable price statement obtained seven statements that have $r$ arithmetic $>\mathrm{r}$ table and declared valid. However, there are three invalid statements because they have $r$ count $<r$ table, namely numbers 27,29 , and 30.

Validity Test Results for ten items after-sales service variable statement obtained eight statements that have $\mathrm{r}$ count $>\mathrm{r}$ table and declared valid. However, there are two invalid statements because they have $\mathrm{r}$ count $<\mathrm{r}$ table, namely numbers 34 and 39.

\section{Reliability Test}

To test the reliability of the instrument used, Cronbach's Alpha coefficient of reliability. The aim is to assess the stability of the size and consistency of respondents in answering the questionnaire. If the Cronbach alpha value is more significant than 0.60 , the survey can be said to meet the concept of reliability.

From the reliability test results for the variable Customer satisfaction with six statement items. Thus, all statement items are stated to be reliable. In other words, from the variable of customer satisfaction, no statement items are deleted or removed because the Cronbach Alpha value for the whole thing is 0.881>0.6 (minimum Cronbach Alpha value requirement) with very high criteria.

From the reliability test results for the quality variable with eight statement items. Thus, all statement items are declared reliable in other words, from the quality variable, no statement items are deleted or removed because the Cronbach Alpha value for the whole thing is 0.851> 0.6 (minimum Cronbach Alpha value requirement) with very high criteria.

From the results of the reliability test for the variable price with seven items statement. Thus, all statement items are declared reliable in other words, from the variable cost, no statement items are deleted or removed because the Cronbach Alpha value for the whole thing is 0.836> 0.6 (minimum requirement of the Cronbach Alpha value) with very high criteria.

From the reliability test results for after-sales service variables with eight statement items. Then, all statement items are declared reliable in other words from the after-sales service variable. No statement items are deleted or removed because the Cronbach Alpha value for the whole thing is $0.800>0.6$ (minimum Cronbach Alpha value requirement) with very high criteria

\section{Data Normality Test}

This test aims to examine whether in a regression model, the dependent variable and the independent variable have a normal distribution or not. A good regression model has a standard or near-normal data distribution. 
Data distribution must be normal or close to normal to meet the normality assumption. The following is a normality test chart image.

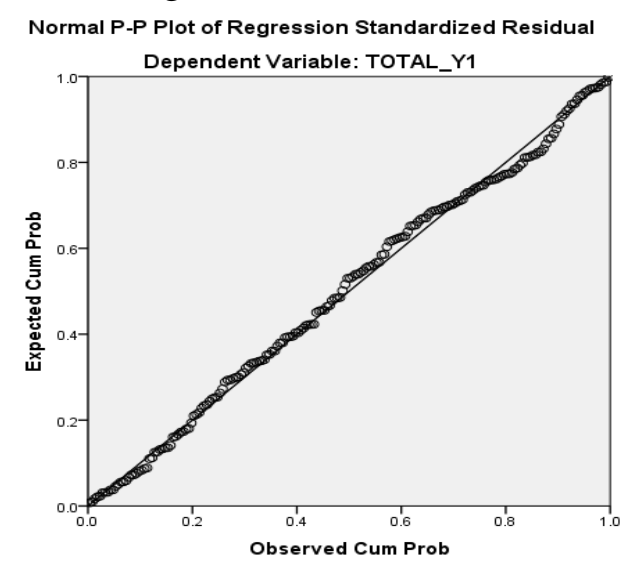

From Figure 1. it can be seen that the points that spread and around the diagonal line and spread also follow the direction of the diagonal line. This proves that the regression model has fulfilled the normality assumption.

4. Homogeneity Test

In multiple regression analyses to get good results, the variance in the disruptive component must be the same. If this assumption cannot be fulfilled, then the data is homogeneous.

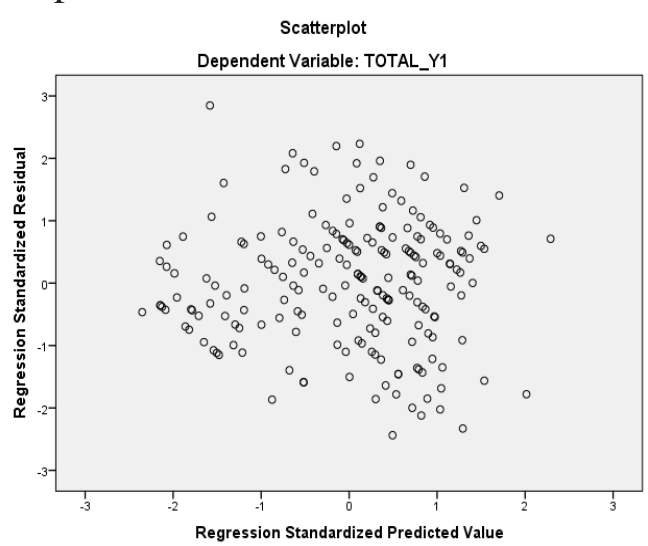

From Figure 2., it can be seen that the points spread randomly do not form specific bright patterns, such as wavy, widened, and then narrowed. Besides these points covered above and below the numbers on the $\mathrm{Y}$ axis, it can be concluded that the data is homogeneous.

\section{Multicollinearity Test}

The purpose of the multicollinearity assumption test is to test whether the regression model found a correlation between independent variables. To detect the presence or absence of multicollinearity symptoms, it is done by looking at the Variance Inflation Factor (VIF); if the VIF value is less than ten, then multicollinearity does not occur.

Based on data processing it is known that among the independent variables used have a VIF value less than 10 , the quality variable has a VIF value of $2.708<10$, the price variable has a VIF value of $2.752<10$ and the after-sales service variable has a VIF value of $1.027<10$. From these results can be concluded that the linear regression model is free from multicollinearity, or there is no correlation between one another. 


\section{Multiple Linear Regression Test}

The calculation of multiple linear regression is used to predict the magnitude of the relationship between the dependent variable (dependent), namely Consumer Satisfaction (Y), with the independent variable (independent) namely Quality (X1), Product Price (X2) and After Sales Service (X3). Where the calculation of the analysis is done using SPSS.

And from the data processing results obtained regression coefficients from the table above as follows:

$$
Y=2,536+0,400(X 1)+0,393(X 2)+0.095(X 3)
$$

From the results of the regression equation above, it can be seen that:

a. $\mathrm{Y}=$ Consumer Satisfaction

The dependent variable, whose value will be predicted by the independent variable. In this study, the dependent variable is customer satisfaction; its value will be predicted by quality (X1), product price (X2), and After Sales Service (X3).

b. Constants $=2,536$

Constant (a) of 2,536 states that if Quality, price, and after-sales service have zero value, customer satisfaction has a value of 2.536 .

c. $\mathrm{b} 1=0,400$

Regression coefficient (b1) of .400 with a positive sign means that the better the quality variable is valued by customers, the higher the effect on customer satisfaction.

d. $\mathrm{b} 2=0.393$

The regression coefficient (b2) of 0.393 with a positive sign means that the better the product price variable perceived by the customer, the higher the effect on customer satisfaction.

e. $\mathrm{b} 3=0.095$

Regression coefficient (b3) of 0.095 with a positive sign means that the better the After Sales Service variable perceived by the customer, the higher the effect on customer satisfaction.

7. Hypothesis testing $\mathrm{t}(\mathrm{t}$-test)

Testing this hypothesis to find out whether the independent variable influences the dependent variable and which the independent variable is the most dominant influence on Job Performance.

The results of the t-test showed that there are three independent variables $(\mathrm{X})$ have a significant effect on the dependent variable (Y). The details can be explained as follows:

a. Quality (X1)

For the Quality variable $(\mathrm{X} 1)$ has a value of $\mathrm{t}=5.306$ with a significance of 0.00 . Sig value $\mathrm{t}<5 \%(0,000<0.05)$. Thus the Ho test was rejected, and Ha was accepted. This shows that quality (X1) has a significant effect on customer satisfaction (Y).

b. Price (X2)

For the price variable $(X 2)$ has a value of $t=5.174$ with a significance of 0.00 . Sig value $t$ $<5 \%(0,000<0.05)$. Thus the Ho test was rejected, and Ha was accepted. This shows that the price $(\mathrm{X} 2)$ has a significant effect on customer satisfaction $(\mathrm{Y})$.

c. After Sales Service (X3)

After Sales Service variable (X3) has a value of $t=2.044$ with a significance of 0.042 . Sig value $\mathrm{t}<5 \%(0.042<0.05)$. Thus the Ho test was rejected, and Ha was accepted. This shows that After Sales Service (X3) has a significant effect on customer satisfaction (Y). 


\section{Hypothesis Testing F (Test F)}

Testing this hypothesis is to determine the effect of the independent variable (independent) with the dependent variable (bound). In this research hypothesis, it is assumed that all quality variables (X1), and price variables (X2) and After Sales Service variables (X3) simultaneously affect consumer satisfaction.

Based on the calculation, results show the magnitude of the influence of the three independent variables together on the independent variable of 93.725 and the Significance of $F$ $=0,000$. So Sig F $<5 \%(0,000<0.05)$, thus $\mathrm{Ha}$ is accepted, and Ho is rejected, which means that simultaneously variables X1, X2, X3 have a significant effect on the variable Y.

So it is evident that the variables of quality, price, and After Sales Service jointly influence consumer satisfaction.

9. Coefficient of Determination (R2)

The ratio of multiple determination (R2) is used to determine the amount of contribution or contribution of the entire independent variable, its effect on the dependent variable (Y). At the same time, the rest is influenced by other variables not included in the model.

Based on data processing, it can be seen that the adjusted value (R2) is 0.583 or $58.3 \%$. This means that the Y variable is explained by $58.3 \%$ by the variable Quality (X1) and Price (X2) and After Sales Service (X3), while the remaining $41.7 \%$ is explained by other variables not examined in this study.

The adjusted R2 value in this study shows a moderate relationship between the dependent variable explained through the independent variables

So the conclusions that can be drawn based on the above hypothesis testing are the variables of quality, price, and after-sales service partially affect customer satisfaction.

\section{Conclusion}

Based on the results of research and discussion described in the previous chapter, the following conclusions can be drawn:

1. Product quality attribute performance significantly influences consumer satisfaction in purchasing city car products.

2. Price-performance attributes significantly influence consumer satisfaction in purchasing city car products.

3. After-sales service attribute performance has a significant effect on Consumer satisfaction in purchasing city car products.

4. Performance attributes of product quality, price, and after-sales service have a significant and joint effect on customer satisfaction in purchasing city car products.

Based on the conclusion, it is suggested as follows:

1. The object of this research is only limited to one automotive industry, a city car so it causes limited research results to make generalizations.

2. For further research, the object of study needs to be added because competition and the development of the automotive industry are numerous.

3. Also, the variables used in this study are minimal because customer satisfaction is not only influenced by several performance attributes. Therefore, the dynamic performance of product 
and service attributes is essential so that customer satisfaction is not only fixed on specific characteristics.

\section{References}

Ancok, Djamaluddin, dan Singarimbun, 1995. Metode Penelitian Survai. LP3ES Jakarta.

Arisutha, Damartaji, 2005. Dimensi Kualitas Pelayanan. Penerbit Gramedia Pustaka, Jakarta.

Engel, James, 1990. (Diterjemahkan oleh Purwoko) Satisfaction; A Behavioral Perspective On The Consumer. Mc-Graw Hill Companies Inc., USA.

Gaspersz, Vincent, 2003. Manajemen Bisnis Total - Total Quality Management. Penerbit PT. Gramedia Pustaka Utama, Jakarta.

Halim, Abdul Barkatulah, 2008, Hukum Perlindungan Konsumen (Kajian Teoretis dan Perkembangan Pemikiran, Nusa Media, Bandung.

Kotler, Philip, 2002, Manajemen Pemasaran : Analisis Perencanaan,Implementasi dan Kontrol, Edisi Milenium. PT. Prenhalindo, Jakarta.

Kotler, Philip. 2005 Manajemen Pemasaran. Alih bahasa; Benyamin Molan, Edisi 11, Jakarta, Indeks.

Lovelock,Christopher.H dan Wright,Lauren.K.2005.Manajemen Pemasaran Jasa.Indeks.

Marcel, Davidson, 2003. Service Quality in Concept and Theory. Published by American Press, USA.

Margaretha, 2003. Kualitas Pelayanan: Teori dan Aplikasi. Penerbit Mandar Maju, Jakarta.

Martul, Shadiqqin, 2004. Implementasi Dimensi Kualitas Pelayanan Konsumen. Penerbit Sinar Grafika,Jakarta.

Nazir, Moh, 2009, Metode penelitian, Jakarta, Ghalia Indonesia.

Norman, Davis, 1992. Service Management System. Prentice Hall Ohio University Press, USA.

Purwoko, Bambang, A., 2000. Asocial Security Highlight in Indonesia: An Economic Perspective. Komunika Jaya Pratama, Jakarta.

Schiffman, Leon. G and Kanuk, Leslie Lazar.2004.Consumer Behavior, 8th edition. Pearson Prentice Hall.

Stemvelt, Robert C., 2004. (Diterjemahkan oleh Purwoko) Perception of Service Quality. Allyn and Bacon, Massachusetts.

Sugiyono, 1998, Metode Penelitian Bisnis, Bandung: Rosdakarya. 
Sunyoto, Hamingpraja, 2004. Jaminan Kualitas Pelayanan Konsumen. Penerbit Liberty, Yogyakarta.

Swastha, Basu dan Hani Handoko,2000, Manajemen Pemasaran (Analisa Prilaku Konsumen), edisi pertama, BPFE Yogyakarta.

Syamsuddin, 1999. Kepuasan Konsumen dalam Pemasaran Jasa. Penerbit Tarsito, Bandung.

Tirtomulyo, Abadi, 1999. Peningkatan Kepuasan Konsumen dalam Tinjauan Pemasaran Jasa. Penerbit Rajawali Press, Jakarta.

Tjiptono, Fandy, 2004. Kepuasan dalam Pelayanan. Penerbit Salemba Empat, Jakarta.

Tjiptono, Fandy, 2004, Manajemen Jasa, Andi, Yogyakarta.

Tri, Celina Siwi Kristiyanti,2009, Hukum Perlindungan Konsumen, Sinar Grafika, Jakarta

Yong, C.Z., Yun, Y.W., Loh, L., 2003. (Diterjemahkan oleh Sutanto). The Quest for Global Quality. Pustaka Delapratasa, Jakarta.

Zeithaml, Bitner, 1990. (Diterjemahkan oleh Purwoko) The Concept of Customer 